\title{
Incretin-based therapies for type 2 diabetes mellitus in Asian patients: Analysis of clinical trials
}

\author{
Melva Louisa, ${ }^{1}$ Madoka Takeuchi, ${ }^{2}$ Masahiro Takeuchi, ${ }^{2}$ Nafrialdi,${ }^{1}$, Rianto Setiabudy ${ }^{1}$ \\ ${ }^{1}$ Department of Pharmacology and Therapeutics, Faculty of Medicine, University of Indonesia, Jakarta, Indonesia \\ ${ }^{2}$ Department of Biostatistics and Clinical Medicine, Kitasato University
}

\begin{abstract}
Abstrak
Tujuan untuk meninjau efikasi dan keamanan terapi diabetes melitus tipe 2 berbasis inkretin (incretin-based therapy) yang saat ini beredar (eksenatid, liraglutid, sitagliptin, vildagliptin) pada populasi Asia.

Metode Kami melakukan pencarian data uji klinik acak yang relevan pada MEDLINE mengenai terapi berbasis inkretin pada diabetes mellitus tipe 2 populasi Asia. Data yang digunakan adalah data efikasi dan keamanan GLP-1 (glucagon-like peptide-1) mimetik dan penghambat DPP-4 (dypeptidyl peptidase-4).

Hasil Empat belas uji klinik acak terapi berbasis inkretin yang mengikutsertakan 3567 pasien diabetes melitus tipe 2 pada populasi Asia (Jepang, Cina, Korea, India). Terapi berbasis inkretin memperbaiki HbA1c lebih besar (hingga -1,42\% pada eksenatid 10 mcg bid, -1,85\% pada liraglutid 0,9 mg qd, -1,4\% pada sitagliptin $100 \mathrm{mg}$ dan -1,4\% pada vildagliptin $50 \mathrm{mg}$ bid) dibandingkan dengan yang ditemukan pada uji klinik populasi Kaukasia, dengan profil keamanan yang setara.

Kesimpulan Efikasi terapi berbasis inkretin pada populasi Asia memperbaiki parameter glikemik lebih besar pada beberapa parameter glikemik dibandingkan dengan pada populasi Kaukasia. Hasil ini mengindikasikan bahwa terapi berbasis inkretin lebih efektif pada populasi Asia dibandingkan dengan populasi Kaukasia. (Med J Indones 2010; 19: 205-12)
\end{abstract}

\begin{abstract}
Aim To review the efficacy and safety data on incretin-based therapies currently available (exenatide, liraglutide, sitagliptin, vildagliptin) for the treatment of type 2 diabetes mellitus in Asian population.

Methods We conducted Medline search of all relevant randomized clinical trials of incretin-based therapies for type 2 diabetes mellitus in Asian populations. Data pertinent to the efficacy and safety of GLP-1 mimetics and DPP-4 inhibitors were extracted and used.

Results We found 14 randomized controlled trials of incretin based-therapy which included 3567 type 2 diabetes mellitus in Asian population (Japanese, Chinese, Korean, Indian). It was shown that incretin-based therapies improved HbA1c at higher extent (up to $-1.42 \%$ in exenatide $10 \mathrm{mcg}$ bid, $-1.85 \%$ for liraglutide $0.9 \mathrm{mg}$ qd, $-1.4 \%$ for sitagliptin $100 \mathrm{mg}$ and $-1.4 \%$ for vildagliptin $50 \mathrm{mg}$ bid) compared to the effects observed in studies with Caucasian population, with comparable safety profile.

Conclusion The efficacy of incretin-based therapies in Asian patients improved glycemic parameters in a higher magnitude on some glycemic parameters compared with those in Caucasian population. These results indicate that incretin-based therapies may be more effective in Asian population than in Caucasian. (Med J Indones 2010; 19: 205-12)
\end{abstract}

Key words: exenatide, incretin, liraglutide, sitagliptin, type-2 diabetes, vildagliptin

Type 2 diabetes mellitus is recognized as a major problem worldwide, with a substantial impacts on morbidity, mortality, quality of life and health care cost. ${ }^{1}$ The WHO estimates that between 2000 and 2030, the world population will increase by $37 \%$ and the number of people with diabetes will increase by $114 \% .^{2}$ In Asia, the proportions of people with type 2 diabetes and obesity are increasing consistently. The Asian region is of prime importance because people in Asia constitute $60 \%$ of the world's population. ${ }^{3}$ Asian population are racially heterogeneous and have differing demographic, cultural and socioeconomic characteristics. Differences in genetic and environmental attributes affecting diabetogenesis and treatment response to medication could also be heterogenous. ${ }^{1,4}$

The increase in type 2 diabetes in Asia differs from that reported in other parts of the world: it develops in a much shorter time, in a younger age group and in people in a much lower body-mass index (BMI). The reasons for ethnic differences in the risk of type 2 diabetes are not entirely understood. ${ }^{1}$

The major etiological components of type 2 diabetes are impaired insulin secretion and impaired insulin action, which are aggravated by the presence and degree of glucotoxicity. Both components might also 
be genetically predetermined. ${ }^{1}$ Lipotoxicity plays an important part in causing insulin resistance and betacell damage. ${ }^{1,5}$

Reports from WHO multinational study and DECODEDECODA study, showed that both insulin resistance and insulin secretion capacity are higher in Caucasians. ${ }^{6-8}$ Ethnic difference among Asian population has also been investigated. DECODA study showed that Asian Indians had a higher prevalence of diabetes compared with Chinese and Japanese. In this study Chinese and Japanese showed almost the same profile of increase in fasting and postprandial glucose with age. ${ }^{9}$ In the follow up to the WHO multinational study of vascular disease in diabetes, it was shown that BMI in Japanese patients was much lower than patients in any of the nations investigated, including Chinese. ${ }^{7}$

In Europe and the USA, insulin resistance with obesity is the predominant pathological manifestation of diabetes; in Asia, impaired insulin secretion is predominant. ${ }^{10}$,

${ }^{11}$ Insulin secretory capacity in Japanese patients with type 2 diabetes has shown to be half of that seen in Caucasian patients, a difference that is particularly pronounced for meal-related secretion. ${ }^{12}$

The incretin hormones released from the gut upon ingestion of meals stimulate insulin secretion. Evidences suggest that 2 most important incretins are glucose-dependent insulinotropic polypeptide (GIP) and glucagon-like peptide-1 (GLP-1). Both hormones powerfully enhance insulin secretion. ${ }^{13}$ While both Asian and Western type 2 diabetes patients generally exhibit incretin defects, they may be more dramatic in Asian patients. ${ }^{10}$ Studies by Nauck et al. indicated that the incretin effect is severely reduced or lost in relatively lean type 2 diabetic patients. ${ }^{14}$ It is noteworthy that GIP is markedly reduced in Type 2 diabetes mellitus in Asia, while the effectiveness of GLP-1 is generally preserved. ${ }^{10}$

The progressive understanding of incretin pathophysiology has made this pathway an attractive target for development of new anti-diabetic agents. Two approaches have been pursued to develop incretinbased anti-diabetic agents: injectable GLP-1 mimetics or analogues, consisting in molecules modified from the native GLP-1 in order to evade DPP-4 inactivation (endogenous GLP-1 itself has a very short half life due to inactivation of enzyme dipeptidyl peptidase-4/ DPP-4); and inhibitors of DPP-4, which aim to enhance endogenous GLP-1 and GIP. ${ }^{15}$
To date there are two GLP-1 mimetics (exenatide and liraglutide) and two DPP-4 inhibitors (sitagliptin and vildagliptin) have been approved by regulatory authority across Asian countries. This review will focus on assessing the efficacy and safety of incretinbased therapy for the treatment of type 2 diabetes in Asian population based on randomized controlled trials published in peer-reviewed journals.

\section{METHODS}

\section{Data Sources}

We conducted a Medline search from inception to November 2009, for randomized controlled trials of incretin-based therapies for type 2 diabetes mellitus in Asian population that were published in Englishlanguage peer-reviewed journals. Other relevant literature sources such as clinical trials databases were also searched (ww.clinicaltrials.gov, www. clinicalstudyresults.org, www.controlled-trials.com).

\section{Study selection}

Data pertinent to the efficacy and safety of GLP-1 mimetics and DPP-4 inhibitors were extracted and used. Studies were included if they met the following criteria: (1) randomized controlled trials with type 2 diabetes, (2) conducted in Asian country settings with Asian ethnic groups, (3) evaluated effect of the drug on $\mathrm{HbA1c}$, (4) published in English language in a peerreviewed journal.

\section{RESULTS}

We found 14 randomized controlled trials of incretin based-therapy which included 3567 type 2 diabetes mellitus in Asian population (Japanese, Chinese, Korean, Indian) (Table 1). The shortest period of therapy was 10 weeks and the longest was 52 weeks (12 weeks placebo-controlled therapy with additional 40 weeks of extension therapy open label, active treatment).

\section{GLP-1 Receptor Agonists/GLP-1 Mimetics}

GLP-1 receptor agonists represent a class of therapies that leverage the glucoregulatory effects of the endogenous incretin hormone GLP-1. This class of agents now includes the subcutaneously injected compounds exenatide and liraglutide. ${ }^{15}$ 
Exenatide was originally derived from the salivary glands of the Gila monster which has 53\% homology with human GLP-1 and found more stable and less rapidly degraded than GLP- $1 .{ }^{15}$ Exenatide is indicated as an adjunctive therapy to improve glycemic control in patients with type 2 diabetes mellitus in combination with metformin, sulfonylurea or thiazolidinedione. Exenatide doses are 5 or $10 \mu \mathrm{g}$ by two subcutaneous injections per day. ${ }^{15,16}$

We found 3 studies of exenatide (Table 1) which included 649 Chinese, Indians, Korean and Japanese type 2 diabetes patients. In these three placebocontrolled clinical trials, exenatide was given as combination therapy with metformin, sulfonylurea, biguanide, thiazolidinedione or combinations of these agents. Compared with placebo, exenatide induced reductions of $\mathrm{HbAlc}$ from -0.6 up to $-1.42 \%$ (placebo adjusted), fasting plasma glucose up to $-1.2 \mathrm{mmol} / \mathrm{L}$ and body weight $(-1.2 \mathrm{~kg})$ in a dose-dependent manner. Adverse events reported in these three studies were predominantly gastrointestinal (nausea, vomiting, diarrhea), nasopharyngitis and hypoglycemia. ${ }^{17-19}$

Liraglutide is a human GLP-1 analog with 97\% homology with GLP-1 and is longer acting than exenatide because of an attached free fatty acid derivative that increases non-covalent binding to albumin and renders it more resistant to DPP-4 degradation, which slows renal clearance and absorption from the subcutaneous injection site. Its half life is about 12 hours, allowing it to be administered once daily. Like GLP-1 and exenatide, liraglutide needs to be injected subcutaneously. ${ }^{20}$

To date, there are 3 studies of liraglutide in Asian population. All of the studies were done in Japanese population which included 890 type 2 diabetes patients. The studies were monotherapy and combination therapy. Liraglutide up to $0.9 \mathrm{mg}$ /day improved $\mathrm{HbAlc}$ up to $-1.36 \%$ (placebo-adjusted), fasting plasma glucose $(-2.43 \mathrm{mmol} / \mathrm{L}){ }^{21-23}$ In the monotherapy study, it was reported that liraglutide $0.9 \mathrm{mg} /$ day decreased body weight by $-2.34 \mathrm{~kg},{ }^{22}$ while in the combination study with other OAD, liraglutide was shown to have a neutral effect on body weight. ${ }^{21,23}$ Homeostasis model assessment for $\beta$-cell function (HOMA- $\beta$ ) and insulin resistance (HOMA-IR) are two widely used parameters to assess beta cell function and the degree of insulin resistance. Lower doses of liraglutide $(0.1 \mathrm{mg}$ qd and $0.3 \mathrm{mg} \mathrm{qd}$ ) did not have beneficial effects toward HOMA-IR and HOMA- $\beta$, while higher doses (0.6 mg qd and $0.9 \mathrm{mg}$ qd) decreased HOMA-IR (-0.32 and -0.53 ) and increased HOMA- $\beta$ (22 and $21.05 \mu \mathrm{U} /$ $\mathrm{mL}$ ), respectively. ${ }^{21}$ Liraglutide was well-tolerated in the three studies. The most common adverse events were gastrointestinal disorders and infections. Liraglutide did not cause hypoglycemia as observed in exenatide studies.

\section{DPP-4 inhibitors}

DPP-4 inhibitors (sitagliptin and vildagliptin) have been successfully developed for clinical use; the magnitude of their effect on GLP-1 is limited to the available endogenous levels of the hormone, which may render them less effective than GLP-1 receptor agonists. ${ }^{10,15}$ However, DPP-4 inhibitors can be administered orally while GLP-1 agonists require administration by injection. DPP-4 activity is reduced by almost $100 \%$ within 15 to 30 minutes of oral administration of DPP-4 inhibitors sitagliptin or vildagliptin, producing 2 -fold increase in mean active GLP-1 levels, with a duration of inhibition in excess of 15 hours because of initial rapid binding to DPP-4, followed by slow phase of tight binding, so that effects persist for 24 hours after administration of a single dose of sitagliptin and vildagliptin. ${ }^{22}$

Currently (December 2009) there are 7 published studies of sitagliptin and 1 study of vildagliptin in Asian population, for a total of 2028 type 2 diabetes patient (1407 patients were conducted in Japanese population and 621 patients were non Japanese, i.e., Chinese, Korean, Indian). ${ }^{24-31} \mathrm{Six}$ of the eight studies assessed the efficacy of DPP-4 inhibitors as monotherapy. There is only one study that compared sitagliptin with other active treatment (voglibose). ${ }^{30}$ One study assessed the efficacy of sitagliptin in Chinese patients with diabetes mellitus and chronic renal insufficiency. ${ }^{27}$

Sitagliptin reduced $\mathrm{HbA} 1 \mathrm{c}$ up to $-1.05 \%$ (placebo adjusted) and fasting plasma glucose up to $-1.4 \mathrm{mmol} / \mathrm{L}$. All of the studies showed that sitagliptin has a neutral effect on body weight, except for the Kadowaki study that showed sitagliptin increased body weight by +0.42 $\mathrm{kg}$. The Nonaka study showed that sitagliptin $100 \mathrm{mg}$ qd decreased HOMA-IR (-0.15) and improved HOMA-b by $9.5 \mu \mathrm{U} / \mathrm{mL}$. Vildagliptin $50 \mathrm{mg}$ bid in Japanese patients reduced $\mathrm{HbA} 1 \mathrm{c}$ by $1.2 \%$ (placebo adjusted), fasting plasma glucose by $1.4 \mathrm{mmol} / \mathrm{L}$, body weight by $0.4 \mathrm{~kg}$, HOMA-IR by 0.4 and increased HOMA-b by $8.2 \mu \mathrm{U} / \mathrm{mL}$. The most common adverse events were gastrointestinal effects and infections (nasopharyngitis, pharyngitis, upper respiratory tract inflammation). 


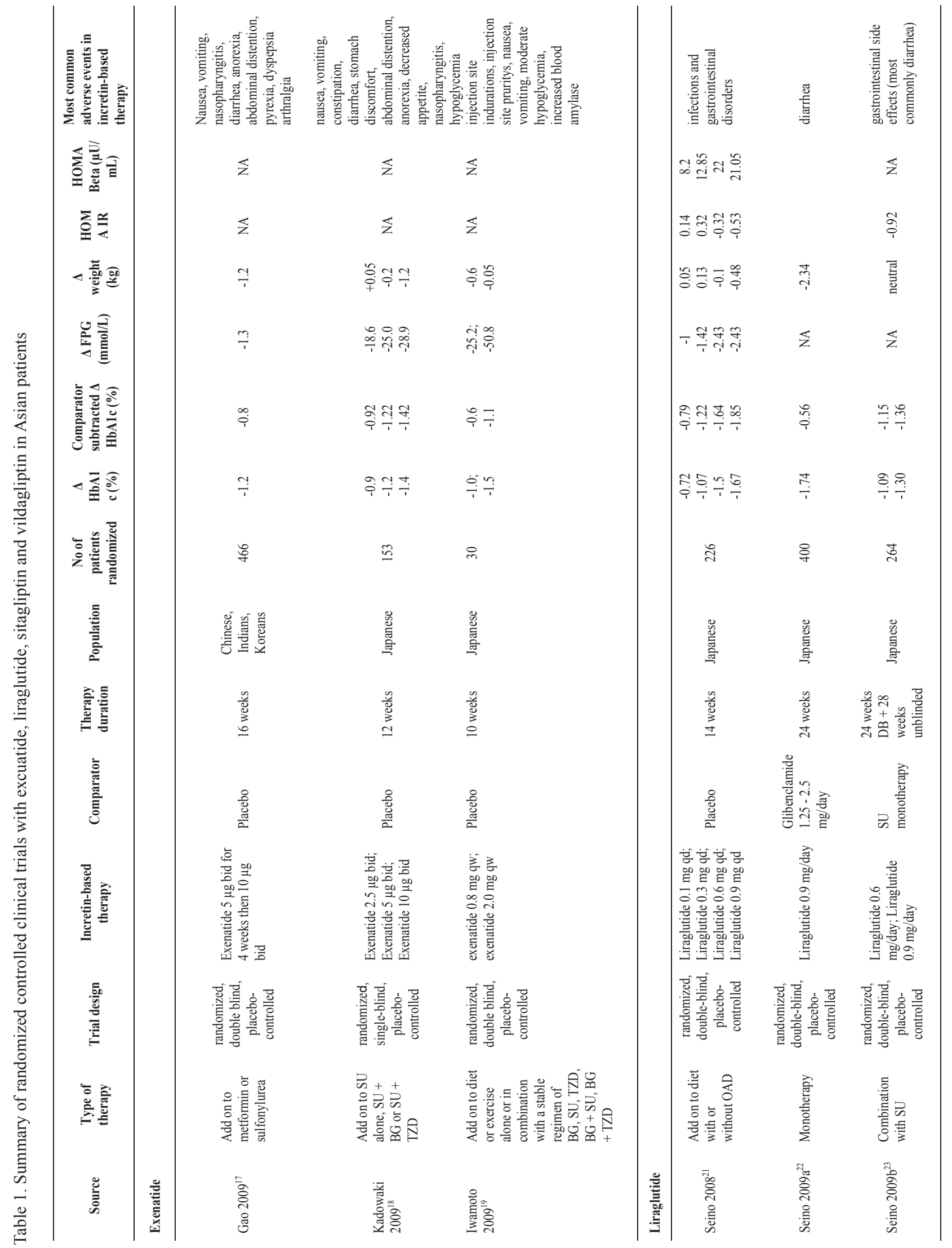




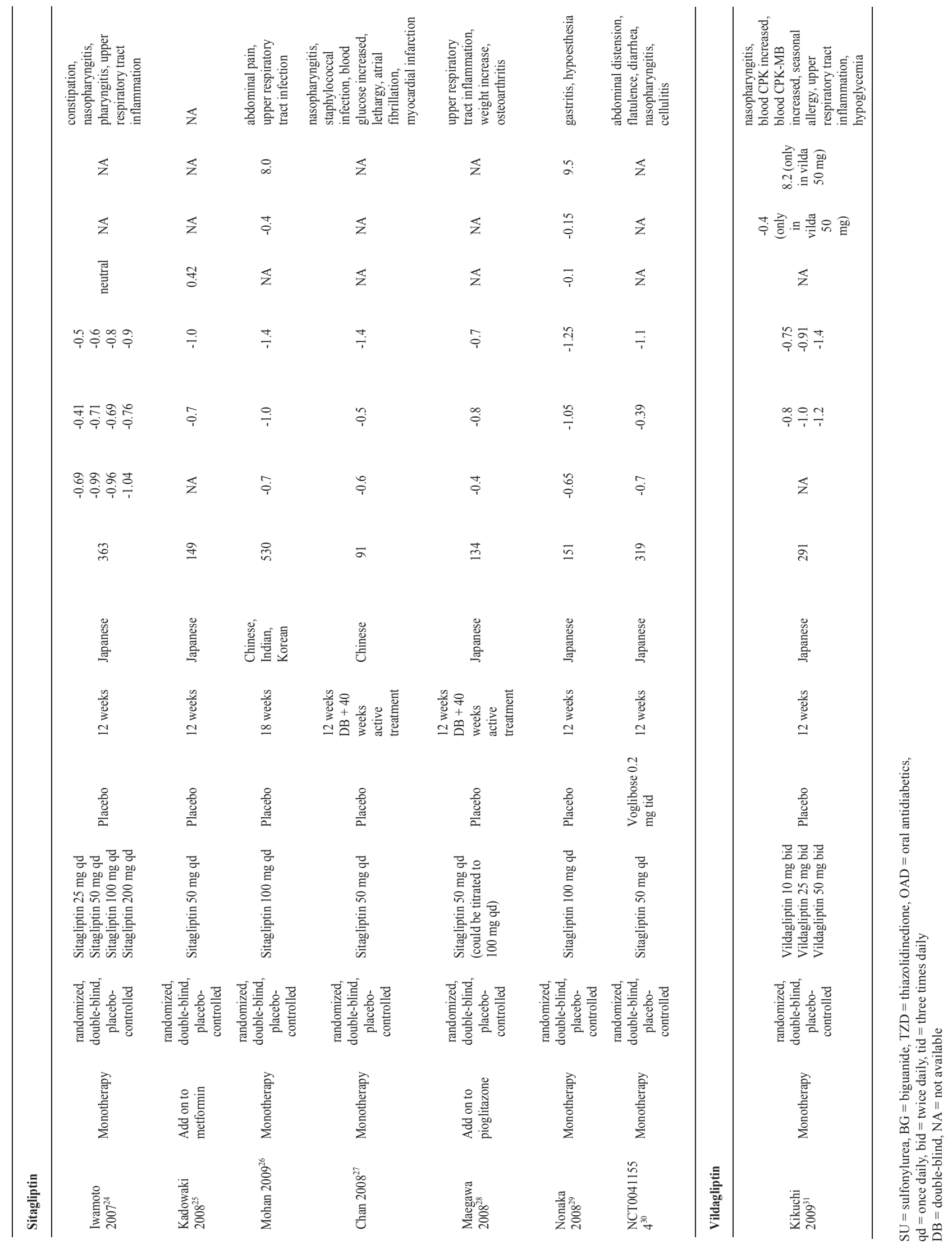




\section{DISCUSSION}

The population in the included studies is generally less obese (typical BMI of $23-25 \mathrm{~kg} / \mathrm{m}^{2}$ ), ${ }^{17-19,21-31}$ compared to the studies in Caucasian population (BMI of $29-35$ $\left.\mathrm{kg} / \mathrm{m}^{2}\right) \cdot{ }^{32-38}$ In non-obese type 2 diabetic patients, defective insulin secretion plays a predominant role on the occurrence of diabetes, rather than insulin resistance..$^{10}$ Incretin-based therapeutic agents exert their pharmacological actions by restoring the complex secretory dysfunctions of patients with type 2 diabetes mellitus. ${ }^{13}$

In the results of the above clinical trial we observed that the reduction of $\mathrm{HbAlc}$ is more prominent in studies with Asian populations than in those with Caucasians. ${ }^{32-39}$

The reduction of $\mathrm{HbAl} \mathrm{c}$ by exenatide was much stronger in Asian population (up to $-1.42 \%$, exenatide $10 \mathrm{mg}$ bid) than in Caucasian which showed a reduction of $-0.78 \%$ (exenatide $10 \mathrm{mcg}$ bid) in the DeFronzo study ${ }^{32}$ and $-1.0 \%$ (exenatide $10 \mathrm{mcg}$ bid) in the Kendall study. ${ }^{33}$

Studies with liraglutide showed even more dramatic results. All of the liraglutide studies were done in Japanese populations which appear to be more sensitive to incretin effects than those observed in Caucasians. Reduction of HbAlc in Japanese population showed similarity in magnitude compared to those observed in LEAD-1 study in lower doses $(0.6 \mathrm{mg} /$ day and $0.9 \mathrm{mg} /$ day in Japanese study versus $1.2 \mathrm{mg} /$ day and $1.8 \mathrm{mg} /$ day in LEAD-1 study). ${ }^{21-23,34}$

Sitagliptin in Asian patients (both Japanese and non Japanese) showed HbAlc improvement at the same doses as in Caucasians but greater in magnitude. Sitagliptin $100 \mathrm{mg}$ in Asian population resulted in reduction of $\mathrm{HbAlc}$ of -0.7 up to $-1.0 \%$ while the Caucasian studies showed reduction of -0.48 up to -0.79 $\% .^{24-30,35-37}$ Kikuchi study also showed that vildagliptin $50 \mathrm{mg}$ twice daily in Japanese patients showed greater reduction of HbAlc (-1.2\%) than Pi-Sunyer and Schweizer studies, which showed reduction of $-0.7 \%$ and $-1.0 \%$, respectively. ${ }^{38,39}$

In terms of body weight, only exenatide showed a consistent weight loss in the three Asian studies, while the liraglutide and sitagliptin showed neutral effects on body weight. Vildagliptin also showed a decrease in body weight in one clinical trial in Japanese population. Caucasian studies showed significant weight reduction with exenatide and liraglutide but not with sitagliptin and vildagliptin..$^{32-40}$ Lack of effect on body weight and the lower initial levels of insulin resistance in the
Asian subjects might explain the small improvement in HOMA-IR observed the above studies. ${ }^{21}$

As expected, $\beta$-cell function (HOMA- $\beta$ ) was improved by all incretin-based therapies, but only in higher dose. This is also consistent with findings in Caucasian studies. $^{34-37}$

The safety profiles observed in the above studies were consistent with previous reports of incretinbased therapies for Caucasian populations, which are predominantly gastrointestinal in nature. No new safety issues were raised from the 14 studies.

Except for exenatide, the incidences of hypoglycemia with incretin-based therapies are generally low. Exenatide enhances insulin secretion from pancreatic $\beta$-cells in a glucose-dependent fashion, wherein insulin secretion decreases as glucose levels normalize. ${ }^{16}$ This mechanism reduces exenatide's potential to cause hypoglycemia. However, as observed in DeFronzo and Kendall studies, dose-dependent increase in the incidence of hypoglycemia was also seen in Asian studies. ${ }^{17-21}$

Incretin-based therapies are a relatively new option for the treatment of patients with type 2 diabetes. These agents hold promise in overcoming the limitations of traditional treatments which are typically associated with weight gain and associated hypoglycemia. The evidences on the efficacy and safety of incretin-based therapies in Asian population so far were encouraging, but many problems still need to be addressed. The majority of the above studies are trials evaluating efficacy of incretin-based therapies versus placebo. Many clinical trials comparing the efficacy of incretinbased therapy versus active control in Asian population are still ongoing. The longest trials available now are up to 52 weeks which provide only a safety profile up to 1 year and sustained efficacy on glycemic parameters. Long-term trials with hard cardiovascular endpoints in Asian type 2 diabetes are still needed. The reasons of the ethnic difference on the response in incretin treatments also remain to be clarified. Global trials with subgroup analysis on ethnic differences might provide a better head to head comparison between races/ethnic groups.

In conclusion, the magnitude of the effect of incretinbased therapies in Asian patients is relatively more pronounced on some glycemic parameters compared with those observed in Caucasian population. These clinical trial results indicate that GLP-1 agents may be more effective in Asian than in Caucasian populations. 


\section{REFERENCES}

1. Ramachandran A, Ma RCW, Snehalatha C. Diabetes in Asia. Article in Press. Lancet. October 28, 2009.

2. Wild S, Roglic G, Green A, Sicree R, King G. Global prevalence of diabetes. Estimates for the year 2000 and projections for 2030. Diab Care. 2004; 27:1047 - 52.

3. Yoon KH, Lee JH, Kim JW, Cho JH, Choi YH, Ko SH, et al. Epidemic obesity and type 2 diabetes in Asia. Lancet. 2006; 368:1681 - 8.

4. Cockram CS. Diabetes mellitus: perspective from the AsiaPacific region. Diab Res Clin Pract. 2000;50 (Suppl 2): S3-7.

5. Unger RH, Zhou YT. Lipotoxicity of beta cells in obesity and in other cause of fatty acid spillover. Diabetes. 2001; 1: S118-21.

6. Chturvedi N, Stevens LK, Fuller JH, Lee ET, Lu M. The WHO Multinational Study Group, Risk factors, ethnic differences and mortality associated with lowerextremity gangrene and amputation in diabetes. The WHO multinational study of vascular disease in diabetes. Diabetologia. 2001; 44 (Suppl 2): S65 - 71.

7. Lee ET, Keen H, Bennett PH, Fuller JH, Lu M. The WHO Multinational Study Group, WHO Multinational Study Group: Follow-up of the WHO Multinational study of vascular disease in diabetes: general description and morbidity. Diabetologia. 2001; 44 (Suppl 2): S3:13.

8. The DECODE-DECODA Study Group, Age, body mass index and type 2 diabetes: associations modified by ethnicity, Diabetologia. 2003; 46: 1063 - 70.

9. The DECODA study Group. Age- and sex- specific prevalence of diabetes and impaired glucose regulation in 11 Asian cohorts. Diab Care. 2003; 26: 1770 - 80 .

10. Seino Y. Relevance of incretins in the treatment of Asian patients with Type 2 diabetes. Diab Res Clin Pract. 2008; 79: S4.

11. Takeuchi M, Okamoto K, Takagi T, Ishii H. Ethnic difference in patients with type 2 diabetes mellitus in interEast Asian populations: A systematic review and metaanalysis focusing on fasting serum insulin. Diab Res Clin Pract. 2008; 81: $370-6$.

12. Fukushima M, Suzuki H, Seino Y. Insulin secretion capacity in the development from normal glucose tolerance to type 2 diabetes. Diab Res Clin Pract. 2004; 66S: S37-43.

13. Holst JJ, Vilsboll T, Deacon CF. The incretin system and its role in type 2 diabetes mellitus. Mol Cell Endocrinol. 2009; 297: $127-36$.

14. Nauck M, Stockman F, Ebert R, Creutzfeldt W. Reduced incretin effect in type 2 (non-insulin-dependent) diabetes. Diabetologia. 1986; 29: 46 - 52.

15. Kendall DM, Cuddihy RM, Bergenstal RM. Clinical application of incretin-based therapy: Therapeutic potential, patient selection and clinical use. Am J Med. 2009; 122: S37 - 50.

16. Verspohl EJ. Novel therapeutics for type 2 diabetes: Incretin hormone mimetics (glucagons-like peptide-1 receptor agonists) and dipeptidyl peptidase-4 inhibitors. Pharm Ther. 2009; 124: 113 - 38 .

17. Gao Y, Yoon KH, Chiang LM, Mohan V, Ning G, Shah S, et al. Efficacy and safety of exenatide in patients of Asian descent with type 2 diabetes inadequately controlled with metformin or metformin and a sulphonylurea. Diab Res Clin Pract. 2009; 83: $69-76$.

18. Kadowaki T, Namba M, Yamamura A, Sowa H, Wolka AM, et al. Exenatide exhibits dose-dependent effects on glycemic control over 12 weeks in Japanese patients with suboptimally controlled type 2 diabetes. Endocr J. 2009; 56:415 - 24.

19. Iwamoto K, Nasu R, Yamamura A, Kothare PA, Mace K, Wolka AM, Linnebjerg H. Safety, tolerability, pharmacokinetics, and pharmacodynamics of exenatide once weekly in Japanese patients with type 2 diabetes. Endocr J. August 25, 2009.

20. Khoo J, Rayner CK, Jones KL, Horowitz M. Incretin-based therapies: new treatments for type 2 diabetes in the new millennium. Ther Clin Risk Manag. 2009;5: 683 - 98.

21. Seino Y, Rasmussen MF, Zdravkovic M, Kaku K. Dosedependent improvement in glycemia with once-daily liraglutide without hypoglycemia or weight gain: A doubleblind, randomized, controlled trial in Japanese patients with type 2 diabetes. Diab Res Clin Pract. 2008;81:161 - 8 .

22. Seino Y, Rasmussen MF, Katayama Y, Kaku K. Liraglutide is statistically superior to glibenclamide at controlling glycemia and weight, with low hypoglycemic risk, and improves beta-cell function in Japanese subjects with T2D; Abstracts of the American Diabetes Association (ADA) 69th scientific session. 2009. Abstract 536-P.

23. Seino Y, Rasmussen MF, Katayama Y, Kaku K. The human GLP-1 analogue liraglutide given once daily provides excellent metabolic control in Japanese patients either as monotherapy or in combination with SU during 52 weeks of treatment. Diabetologia. 2009; 52 (Suppl 1): S292.

24. Iwamoto Y, Nonaka K, Okada A, Okuyama K, Stein PP. Dose-response relationship for glycemic efficacy, safety and tolerability of sitagliptin after 12 weeks of treatment in Japanese patients with type 2 diabetes mellitus. Diabetologia. 2007; 50 (Suppl 1): S366.

25. Kadowaki T, Tajima N, Odawara M, Nishii M, Nonaka K, Stein PP. Sitagliptin added to ongoing treatment with metformin improved glycemic control and was well tolerated in Japanese patients with type 2 diabetes (T2DM); Abstracts of the American Diabetes Association (ADA) 68th scientific session. 2008. Abstract 2135-PO.

26. Mohan V, Yang W, Son HY, Xu L, Noble L, Langdon RB, et al. Efficacy and safety of sitagliptin in the treatment of patients with type 2 diabetes in China, India and Korea. Diab Res Clin Pract. 2009; 83:106-16.

27. Chan JCN, Scott R, Ferreira JCA, Sheng D, Gonzales E, Davies MJ, et al. Safety and efficacy of sitagliptin in patients with type 2 diabetes and chronic renal insufficiency. Diab Obes Metab. 2008; 10: $545-55$.

28. Maegawa H, Kashiwagi A, Tajima N, Kadowaki T, Nonaka K, Okamoto T. Diabetologia. 2008; 51 (Suppl 1): S 365.

29. Nonaka K, Kakikawa T, Sato A, Okuyama K, Fujimoto G, Kato N, et al. Diab Res Clin Pract. 2008; $79: 291-8$.

30. NCT00411554. Study of Sitagliptin in patients with type 2 diabetes mellitus who have inadequate glycemic control on diet/exercise therapy. Available URL: www.clinicaltrials.gov

31. Kikuchi M, Abe N, Kato M, Terao S, Mimori N, Tachibana $\mathrm{H}$. Vildagliptin dose-dependently improves glycemic control 
in Japanese patients with type 2 diabetes mellitus. Diab Res Clin Pract. 2009; 83: 233 - 40.

32. DeFronzo, Ratner RE, Han J, Kim DD, Fineman MS, Baron AD. Effects of exenatide (exendin-4) on glycemic control and weight over 30 weeks in metformin-treated patients with type 2 diabetes. Diab Care. 2005; 28: 1092 - 100.

33. Kendall DM, Riddle MC, Rosenstock J, Zuang D, Kim DD, Fineman MS, et al. Effects of exenatide (exendin-4) on glycemic control over 30 weeks in patients with type 2 diabetes treated with metformin and a sulfonylurea. Diab Care. 2005; 28: 1083 - 91.

34. Marre M, Shaw J, Brandle M, Bebakar WMW, Kamaruddin NA, Strand J, et al. Liraglutide, a once-daily human GLP-1 analogue, added to a sulphonylurea over 26 weeks produces greater improvements in glycemic and weight control compared with adding rosiglitazone or placebo in subjects with type 2 diabetes (LEAD-1 SU). Diabet Med. 2009; 26: $268-78$

35. Aschner P, Kipnes MS, Lunceford JK, Sanchez M, Mickel C, Williams-Herman DE. Effct of the dipeptidyl peptidase-4 inhibitor sitagliptin as monotherapy on glycemic control in patients with type 2 diabetes. Diab Care. 2006; 29: 2632 - 7 .
36. Raz I, Hanefeld M, Xu L, Caria C, Williams-Herman D, Khatami H. Efficacy and safety of dipeptidyl peptidase-4 inhibitor sitagliptin as monotherapy in patients with type 2 diabetes mellitus. Diabetologia. 2006; 49: 2564 - 71 .

37. Charbonnel B, Karasik A, Liu J, Wu M, Meininger G. Efficacy and safety of the dipeptidyl peptidase-4 inhibitor sitagliptin added to ongoing metformin therapy in patients with type 2 diabetes inadequately controlled with metformin alone. Diab Care. 2006; 29: 2638 - 43.

38. Pi-Sunyer FX, Schweizer A, Mills D, Dejager S. Efficacy and tolerability of vildagliptin monotherapy in drug-naive patients with type 2 diabetes. Diab Res Clin Pract. 2007; 76: $132-8$.

39. Schweizer A, Couturier A, Foley JE, Dejager S. Comparison between vildagliptin and metformin to sustain reductions in $\mathrm{HbA} 2 \mathrm{c}$ over 1 year in drug-naïve patients with type 2 diabetes. Diabet Med. 2007; 24: 955 - 61.

40. Feinglos MN, Saad MF, Pi-Sunyer FX, An B, Santiago O. Effects of liraglutide (NN2211), a long-acting GLP-1 analogue, on glycemic control and bodyweight in subjects with type 2 diabetes. Diabet Med. 2005; 22: 1016 - 23. 